https://doi.org/10.15407/scin16.06.095

VNUKOVA, N.M. ${ }^{1}$, TOKHTAMYSH, T.O. ${ }^{2}$, YAGOLNITSKIY, O.A. ${ }^{2}$, and HRANKO, K.B. ${ }^{2}$

${ }^{I}$ Simon Kuznets Kharkiv National University of Economics, 9. Science Ave., Kharkiv, 61766, Ukraine, +380 57702 0304, post@hneu.edu.ua

${ }^{2}$ Kharkiv National University of Civil Engineering and Architecture, 40, Sumska St., Kharkiv, 61002, Ukraine, +380 57700 1056, office@kstuca.kharkov.ua

\title{
INNOVATIVE APPROACH TO ESTIMATING COSTS OF VEHICLE PARKING SERVICES
}

Introduction. The analysis of the state of the vehicle parking system in Ukraine has shown that the organizational, regulatory, and financial conditions of its operation do not meet the needs of road users, user requirements and European practices.

Problem Statement. Due to the congestion of the street and road network of large cities of Ukraine by vehicles, there is a need to substantiate and determine zoning indicators to establish the appropriate cost of services for the use of paid parking lots.

Purpose. Development of zoning indicators when calculating the cost of services for the use of sites for paid parking of vehicles.

Materials and Methods. General and special methods of economic theory, scientific knowledge are used: system, comparative analysis, etc.

Results. According to the results of experiments on the load of day platforms for paid parking of vehicles, 3 zones have been identified. Most of the sites fall into Zone I and Zone II because of their load level of more than 60\%. The zoning indicators have been developed for the calculation of the cost of services for the use of sites for the payment of parking vehicles. When assessing the priority of the influential factors on the zoning indicator, the scale of relative importance of $T$. Saati is used. It has been determined that zoning is the main factor influencing the step of adjusting the tariff rate for paid parking of vehicles. The results of the calculations showed that the step of adjusting the tariff should be 0.4.

Conclusion. The development can be used in the work of utilities that provide vehicle parking services, in particular, in the preparation and submission of settlement materials and documents for the formation of tariffs for services for the use of daytime parking lots for paid parking.

Keywords: zoning indicator, parking lots, congestion, vehicles, tariff.

The creation of organizational and economic conditions for the development of parking space for vehicles is a necessary requirement of a modern European city, which will ensure its social and economic development by increasing the revenue part of the budget through

Цитування: Vnukova N.M., Tokhtamysh T.O., Yagolnitskiy O.A., and Hranko K.B. Innovative Approach to Estimating Costs of Vehicle Parking Services. Nauka innov. 2020. V. 16, no. 6. P. 95-104. https://doi.org/ $10.15407 / \operatorname{scin} 16.06 .095$ 
tax revenues and creating an attractive investment climate.

Inefficient management of parking in the streets of a large city is one of the main problems of assessing the quality of urban life, budget and transport functions. The factors that have the greatest impact on these problems can be divided into three main parts:

- elements of opacity that are subjectively (in the opinion of the public) or objectively related to the collection of tolls;

- absence of strictly regulated procedure of application of parking rules (for example, car parking within specially designated places is carried out with crossing of marking lines);

- ineffective permissive laws and procedures (for example, permission to park on the pavement provided that pedestrian traffic remains at least $2 \mathrm{~m}$ contradicts the intentional arrangement of specially designated places on sidewalks).

The existing parking rules do not take into account the differences that exist in different parts of the city, therefore, in order to reduce the congestion of the road network of large cities of Ukraine by means of transport, grounding and definition of zoning indicators for establishing the appropriate cost of services for using paid parking lots is becoming topical issue where innovative marketing approaches are used.

Information and theoretical bases of the research are scientific publications of domestic and foreign researchers and practitioners such as: Borovikov V.P. [1], Bureyeva N.N. [2], Illyashenko N.S. [3], Saati T. [4], as well as a wide range of legislative and regulatory acts regulating the setting of tariffs using zoning indicators to calculate the cost of services for using paid vehicle parking lots. In particular: The Law of Ukraine on Road Traffic [5], the Law of Ukraine on Improvement of Human Settlements [6], the Law of Ukraine on Amendments to Certain Legislative Acts of Ukraine Regarding the Vehicle Parking Reform [7], Resolution of the Cabinet of Ministers of Ukraine on Approval of Vehicle Parking Rules [8], etc.
The analysis of the existing state of the vehicle parking system in Ukraine shows that the organizational, regulatory and financial conditions of the operation of this system do not meet the needs of road users, the requirements of users, residents of the city and European practices in this sphere.

Development of theoretical provisions and practical recommendations for the application of zoning indicators when calculating the cost of services for using paid parking of vehicles.

In order to meet the needs of consumers of services of paid vehicle parking in the modern large city, the following problems need to be solved: to increase the throughput of transport routes; to increase the level of road safety; to raise the level of improvement of the territory of the city; to regulate the state and improve the culture of vehicle parking; to provide control over the compliance of the vehicle owners with the proper fulfillment of the requirements of the current legislation in the field of site improvement and traffic. The solution of these problems requires the use of an innovative approach to reforming the field of vehicle parking in a big city.

By definition [3], marketing innovation means implementing traditional functions and marketing objectives when creating and distributing innovations to best meet the needs and demands of consumers and producers.

In order to more effectively meet the needs of users requests in vehicle parking, the classification of marketing innovations proposed by [3] has been applied as follows:

- innovations in place - distribution of daytime vehicle parking places to their respective zones;

- innovations in product - provision of services for the paid parking of vehicles taking into account zoning requirements;

- innovations in price - adjustment of tariffs for the use of daytime lots for paid parking of vehicles;

- innovations in promotion - interaction between those who provide services and consumers of these services;

- combining these components of marketing innovations in the sphere of vehicle parking. 
The activity of vehicle parking in Ukraine is regulated by the current normative and legal acts. According to Article 6 of the Law of Ukraine on Road Traffic, the competence of city councils and their executive bodies, district councils and district state administrations in the field of traffic includes the placement and equipment of daytime vehicle parking lots in the streets and roads of settlements, as well as the control over their activities. The arrangement of daytime lots is carried out in accordance with norms, regulations, standards and other normative documents [5].

According to Article 52 of the Law of Ukraine on Road Traffic when persons park vehicles on a daytime parking lot, they pay for the services of using it in accordance with the tariff set by the local self-government body in accordance with the order of tariff for the services of using a daytime vehicle parking lot approved by the Cabinet of Ministers of Ukraine [9]. In addition, part 3 of Article 28-1 of the Law of Ukraine on the Improvement of Human Settlements [6] provides that local governments shall set tariffs for using daytime lots of paid parking of vehicles on the basis of the order of formation of such tariffs approved by the Cabinet of Ministers of Ukraine [9].

The Resolution of the Cabinet of Ministers of Ukraine on the Procedure for the Tariff Formation for Services of Using Paid Vehicle Parking Lots [9] defines a payment for vehicle parking as a fee for the maintenance and servicing of paid parking lot calculated in accordance with the planned cost of the operator's services.

However, the specified regulatory acts do not take into account the differentiation of tariffs depending on the zone of the daytime parking lot. Therefore, it is necessary to solve this issue using innovative marketing approaches to meet the needs of consumers of these services.

In this article, the study was conducted on the example of a large city, which according to the State Building Regulations 360-92** [10] is a territory with a population of more than 250 thousand people.
The considered big city has 50 daytime lots for paid parking of vehicles from a total number of parking lots. For the adequacy of the research conducted, the assigned numbers of daytime lots were kept according to their general list in the city in question. The authors analyzed the congestion of these lots for the selection of promising zones based on experiments. The survey was conducted in two stages:

- during the week in August 2018 year (Experiment 1);

- during the week in September 2018 year (Experiment 2).

It consisted in fixing the number of cars parked on parking lots, hourly - from 08:00 to 18:00. The status of the place where the car was parked was also registered (official parking place, parking place for disabled cars). Before the survey was tasked - to calculate the number of free and busy parking places on the daytime lots during the day to assess the congestion of each of them.

As a result of the conducted Experiments, the average congestion of each daytime lot for the paid parking of vehicles is calculated as the ratio of the actual number of vehicles to the total number of parking places on average per working day, which is shown in table 1 in increments of this parameter.

The data presented in Table 1 reflect the average congestion of daytime lots for paid parking of vehicles in the range from $51 \%$ to $96 \%$. According to the results of the first experiment, it was found that 44 parking sites had less than $70 \%$ of the load. Due to the fact, that the survey was conducted in August, when a significant number of vehicle owners were on vacation or out of town.

Table 1. Breakdown of Payday Parking Areas by Congestion Level (Experiment 1, Experiment 2)

\begin{tabular}{|l|c|c|}
\hline Congestion level & Experiment 1 & Experiment 2 \\
\hline From 0.51 to 0.60 & 31 & 14 \\
From 0.61 to 0.70 & 13 & 14 \\
From 0.71 to 0.80 & 3 & 7 \\
From 0.81 to 0.90 & 2 & 10 \\
More 0.91 & 3 & 7 \\
\hline
\end{tabular}


So demand for parking services was low. The results of the second experiment differ in the level of loads due to the increase of business activity in September (24 park sites had more than $70 \%$ load). The average occupancy rate of all study objects in the second experiment was $79 \%$.

The average value of the congestion of the daytime lots for paid parking of vehicles, obtained during Experiment 1, is lower at 11.7 sequential point from the results of Experiment 2, which is explained by a decrease in business activity in summer period. For example, lot number 6 during Experiment 1 had an average daily congestion of 0.89 ( $4^{\text {th }}$ place according to sorting), and in Ex- periment 2 the congestion was 0.968 ( $3^{\text {rd }}$ place according to sorting). Lot number 86 (Experiment 1$)$ had a congestion of 0.565 ( $41^{\text {st }}$ place by sorting), in Experiment 2 congestion made up 0.640 ( $39^{\text {th }}$ place according to sorting).

The grouping by day zones for paid parking of vehicles by the results of the experiments is given in Table 2.

Results of Experiment 1 and Experiment 2 on congestion of daytime lots for paid parking of vehicles in Table 2 allow allocating 3 zones. Most of the daytime lots for paid parking of vehicles fall into zones 1 and 2, that is, they have the congestion of more than $60 \%$.

Table 2. Grouping by Day Zones

for Paid Parking of Vehicles by Experiment

\begin{tabular}{|c|c|c|c|c|c|c|c|}
\hline \multirow{2}{*}{$\begin{array}{l}\text { Parking } \\
\text { lot number }\end{array}$} & \multicolumn{3}{|c|}{ Loading of paid parking lots for daily use } & \multirow{2}{*}{$\begin{array}{l}\text { Parking } \\
\text { lot number }\end{array}$} & \multicolumn{3}{|c|}{ Loading of paid parking lots for daily use } \\
\hline & Experiment 1 & Experiment 2 & Zone & & Experiment 1 & Experiment 2 & Zone \\
\hline 16 & 0.95 & 0.98 & 1 & 3 & 0.66 & 0.862 & 1 \\
\hline 97 & 0.93 & 0.979 & 1 & 10 & 0.65 & 0.857 & 3 \\
\hline 6 & 0.89 & 0.977 & 1 & 107 & 0.61 & 0.75 & 3 \\
\hline 78 & 0.91 & 0.968 & 1 & 35 & 0.61 & 0.73 & 3 \\
\hline 108 & 0.78 & 0.962 & 3 & 21 & 0.6 & 0.7 & 3 \\
\hline 80 & 0.87 & 0.96 & 2 & 59 & 0.59 & 0.69 & 1 \\
\hline 104 & 0.78 & 0.957 & 3 & 106 & 0.59 & 0.69 & 1 \\
\hline 14 & 0.79 & 0.95 & 3 & 71 & 0.59 & 0.69 & 2 \\
\hline 105 & 0.785 & 0.948 & 3 & 112 & 0.59 & 0.67 & 2 \\
\hline 2 & 0.752 & 0.947 & 1 & 114 & 0.59 & 0.67 & 1 \\
\hline 5 & 0.75 & 0.945 & 1 & 23 & 0.59 & 0.65 & 1 \\
\hline 103 & 0.737 & 0.942 & 1 & 94 & 0.59 & 0.65 & 3 \\
\hline 084 & 0.72 & 0.939 & 1 & 8 & 0.589 & 0.64 & 3 \\
\hline 082 & 0.71 & 0.937 & 1 & 86 & 0.56 & 0.64 & 3 \\
\hline 111 & 0.71 & 0.93 & 3 & 70 & 0.573 & 0.64 & 1 \\
\hline 9 & 0.71 & 0.9 & 2 & 27 & 0.56 & 0.63 & 2 \\
\hline 4 & 0.71 & 0.898 & 2 & 26 & 0.55 & 0.62 & 1 \\
\hline 83 & 0.71 & 0.891 & 1 & 25 & 0.55 & 0.62 & 3 \\
\hline 11 & 0.71 & 0.89 & 1 & 93 & 0.55 & 0.61 & 3 \\
\hline 77 & 0.71 & 0.887 & 1 & 73 & 0.51 & 0.16 & 1 \\
\hline 17 & 0.71 & 0.884 & 2 & 7 & 0.51 & 0.515 & 1 \\
\hline 24 & 0.71 & 0.88 & 3 & 79 & 0.51 & 0.514 & 1 \\
\hline 101 & 0.71 & 0.876 & 3 & 13 & 0.51 & 0.514 & 2 \\
\hline 55 & 0.66 & 0.872 & 1 & 92 & 0.51 & 0.512 & 1 \\
\hline 22 & 0.66 & 0.868 & 1 & 36 & 0.515 & 0.511 & 1 \\
\hline
\end{tabular}


A cluster analysis [2] has been used to confirm the distribution of daytime lots for paid parking of vehicles by zones, which analyzes data containing information on the sampling of objects and arranges them in relatively homogeneous groups (clusters). That is, cluster analysis allows allocating objects to groups according to certain criteria.

The data for the cluster analysis have selected the results of Experiment 1 and Experiment 2 and the criterion of the distribution of streets by functional values is taken into account. All daytime lots for paid parking of vehicles received their classification number from 1 to 3 depending on the value of the street on which there is a parking lot, according to the master plan of the studying city: 1 - streets of mainstream value, 2 - streets of regional significance, 3 - others.

The results of the experiments have been standardized so that all components have the same contribution to the calculation. The standardization of indicators was carried out according to the formula (1) [1]:

$$
Z=\frac{x-\bar{x}}{\sigma}
$$

where $x$ is variable; $\bar{x}, \sigma-$ is respectively the mean and the mean square deviation of $x$.

The standardized data clustered to three clusters. The transition from objects to distances between objects is essential. The distance (metric) between objects is one of the measures of similarity. The smaller the distance between the objects, the more they are similar. The distance from an object to a set of objects can be determined as follows: each class of objects has a center of gravity [1]. Thus, the distances between the clusters were: between the first and second cluster was 1.070270, between the second and third was 2.451564 , between the first and third was 1.464833 .

The obtained clustering results correlate with differences in congestion levels of daytime lots for paid parking of vehicles presented in Figure 1.

Figure 1 shows a significant change in the level of congestion:

- by 20\% (7\% as a result of Experiment 1) between parking lots number 93 and number 73;

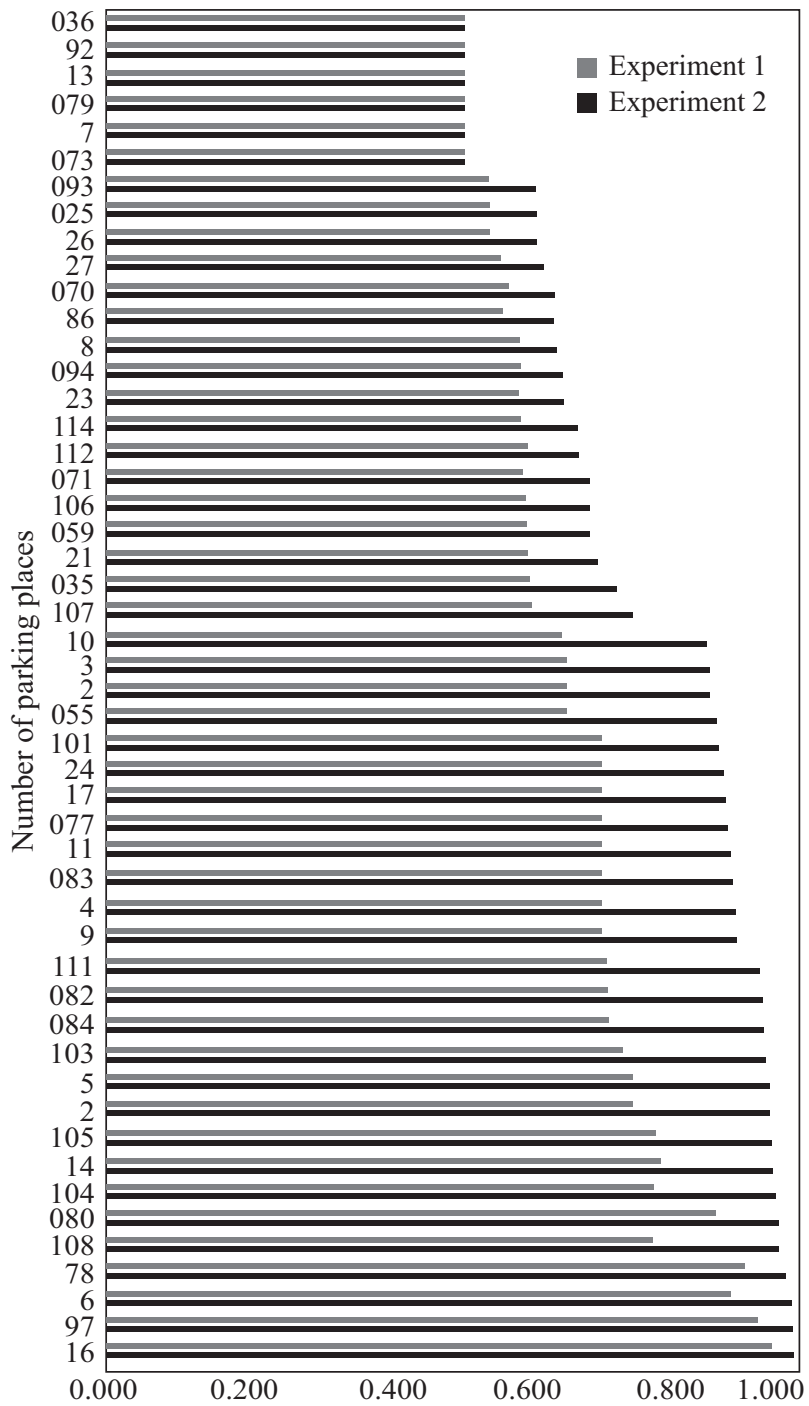

Fig. 1. Sorting of lots for daytime paid parking of vehicles, by average congestion per working day as a result of Experiment 1 and Experiment 2

- by 14\% (7\% as a result of Experiment 1) between parking lots number 10 and number 107, which confirms the necessity of assigning these areas to different zones.

Thus, based on the results of the conducted research, the distribution of daytime lots for paid parking of vehicles divided into 3 zones is confirmed:

- Zone I includes 27 daytime lots for paid parking of vehicles that are most loaded;

- Zone II has 17 lots with average congestion; 
- Zone III includes 6 lots with the least degree of congestion.

This distribution allows the use of different zoning indicators for parking lots depending on the congestion coefficient.

In order to find ways to increase the satisfaction level of parking needs of vehicle owners, a survey on the internet was conducted among vehicle owners. The questionnaire is posted on the official website of the regional Union of Entrepreneurs. The list of questions was related to the frequency of paid parking use, time of use, problems with parking, the validity of the current tariff and the need for its differentiation, the expediency of increasing the number of paid parking and the introduction of different parking tariffs for different zones of the city. The survey was attended by 2387 respondents, representing the interests of officially registered owners of vehicles of the city, which is 423,000 people. According to the results of the survey, it has been established that more than $70 \%$ of car owners interviewed use daytime parking lots, and a third part uses almost daily.

Vehicle owners most frequently use daytime parking lots up to 1 hour $-42 \%$ of the respondents, from 1 to 2 hours $-38.3 \%$, which is also confirmed by the results of Experiment 1 and Experiment 2 . Only $8.6 \%$ of respondents use daytime parking lots for the entire time of the day.

Considering the complexity of parking throughout the day, the survey showed that the difficulties with parking a vehicle did not occur in almost $26 \%$ of car owners, about $65 \%$ of respondents indicated that the complexity was sometimes or not often. Difficulties with parking of vehicles appeared only in $10 \%$ of respondents who pointed to the places of greatest demand for parking - the city center. More than $60 \%$ of car owners consider it necessary to increase the number of parking places. Almost $61 \%$ of respondents emphasize that an increase in parking places is advisable if the parking tariff increase is insignificant.

In connection with the coming into force of the Law of Ukraine on Amendments to Certain Legis- lative Acts of Ukraine Regarding the Vehicle Parking Reform [7], the issue of increasing the number of paid parking lots becomes a topical issue. However, the opinions of car owners were divided relative to the increase of tariffs on daytime paid vehicle parking lots in the city center. Thus, $40.7 \%$ of respondents admit a slight increase in tariffs, another $8.6 \%$ believe that the tariff in the city center should be significantly higher and $50.6 \%$ oppose the increase of tariff for services of using paid vehicle parking lots.

An absolute majority of interviewed respondents consider it necessary to differentiate the tariff for vehicle parking lots with a higher degree of congestion. Accordingly, an important task is to justify the application of zoning indicators to calculate the cost of services for using daytime paid vehicle parking lots. The tool for solving this problem is proposed by the authors to determine not the very coefficient that may have a subjective value, but the step of changing the zoning coefficient to adjust the existing tariff for vehicle parking for each of the allocated zones in a large city by the method of analysis of the hierarchy [4].

The method of analysis of the hierarchy enables substantiating the solution of multicriteria problems in complex hierarchical structures, as well as eliminating the subjectivity of experts' evaluations when choosing the factors that have the greatest influence on the choice of the step of the zoning coefficient.

To determine the factors of influence on the step of the zoning indicator, the method of T. Saati was used. The survey was conducted among specialists of the Municipal Infrastructure Department and vehicle owners. According to the survey results, the following factors of influence on the step of zoning indicator are allocated: congestion of the transport system of the city; level of organization of traffic; congestion of the daytime parking lots; zoning; functional value of the street; city category; demand for parking lots.

A hierarchical model for solving the problem of choosing the step of the zoning indicator by various features is shown in Fig. 2. 


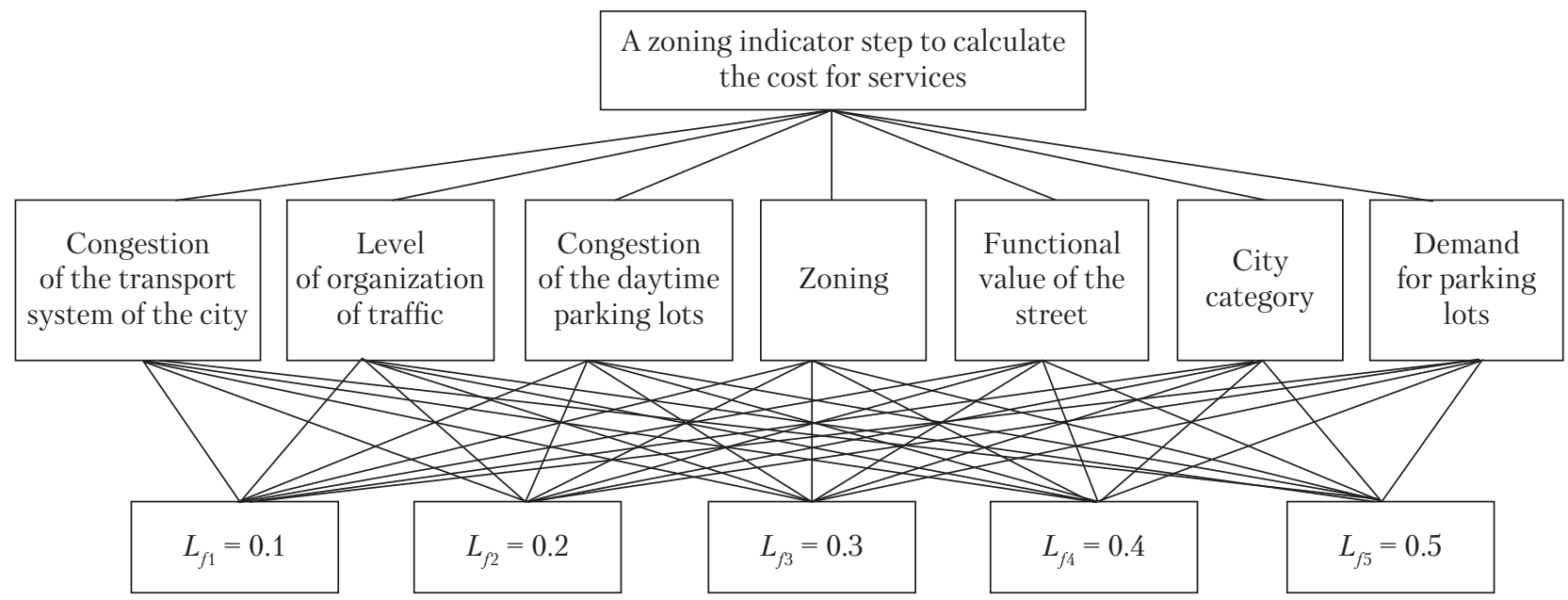

Fig. 2. Hierarchical model of solving the problem of choosing a zoning indicator step to calculate the cost for services of using daytime paid vehicle parking lots

As can be seen from Fig. 2, the third (lower) level of the model makes up the steps of the zoning coefficient (from 0.1 to 0.5 ), the second is the influence factors on the step of the zoning indicator, the upper level reflects the given task. The range of coefficients is chosen in such a way that its application does not affect the sharp increase in the tariff and does not violate the rights of consumers of services for paid parking of vehicles.

The next step in choosing a zoning indicator step for calculating the cost for service of using day-time paid vehicle parking lots is to evaluate the benefits of properties by determining the measures of these properties in accordance with the scale proposed by the systemologist T. Saati [4]. Such a measure is formed as a result of judgement statements about the degree of influence (importance) of these factors.

To evaluate the priority factors of influence on the step of the zoning coefficient, a matrix of paired comparisons of the characteristics of the analyzed system, which is a square $\mathrm{n}$ is dimensional matrix, is compiled (Table 3).

In the Table 3 below, $V_{i}$ is the main eigenvector calculated by the formula:

$$
V_{i}=\sqrt[n]{\Pi_{j=1}^{n} a_{i j}} .
$$

The component of the priority vector $\left(P_{i}\right)$ is calculated as the normalized value of the main eigenvector:

$$
P_{i}=\frac{V_{i}}{\sum_{j=1}^{n} V_{i}} .
$$

Table 3 shows that zoning is the main factor influencing the step of adjusting the tariff rate for vehicle parking, since it has the highest value $P_{i}(0.39)$.

On the basis of the performed calculations, the consistency of the obtained indicators was determined. As a measure of coherence, two indicators are used: Coherence Index $(C I)$; Coherence Ratio $(C R)$.

Coherence Index is calculated by the following formula (4):

$$
C I=\frac{\lambda_{\max }-n}{n-1} .
$$

The $\lambda_{\max }$ value for estimating the coherence ratio can be calculated using the following formula:

$$
\lambda_{\text {max }}=\sum_{j=1}^{n} M_{j} \cdot P_{j},
$$

where $M_{j}=\sum_{j=1}^{n} a_{i j}$ is a sum of elements of the $i$-th column of the matrix; $P_{j}$ is a vector component of the matrix priority that being analyzed.

For each column of the matrix given in Table 3 $M_{j}$ is $(7.41,20.33,4.55,28,2.41,26,10.83)$.

According to [4], $\lambda_{\max }$ equal to 7.38 and Coherence Index is 0.06 . In order to evaluate whether 
Table 3. The Priority of the Factors Influencing the Step of the Zoning Indicator

\begin{tabular}{|l|c|c|c|c|c|c|c|c|c|}
\hline \multicolumn{1}{|c|}{ Factors } & $\begin{array}{c}\text { Congestion } \\
\text { of the transport } \\
\text { system of the city }\end{array}$ & $\begin{array}{c}\text { Level of } \\
\text { organization } \\
\text { of traffic }\end{array}$ & $\begin{array}{c}\text { Congestion } \\
\text { of the daytime } \\
\text { parking lots }\end{array}$ & Zoning & $\begin{array}{c}\text { Functional } \\
\text { value of the } \\
\text { street }\end{array}$ & $\begin{array}{c}\text { City } \\
\text { category }\end{array}$ & $\begin{array}{c}\text { Demand } \\
\text { for parking } \\
\text { lots }\end{array}$ & $V_{i}$ & $P_{i}$ \\
\hline $\begin{array}{l}\text { Congestion of the } \\
\text { transport system of } \\
\text { the city }\end{array}$ & 1 & 3 & $1 / 2$ & $1 / 3$ & 4 & 3 & 2 & 1.42 & 0.14 \\
$\begin{array}{l}\text { Level of organiza- } \\
\text { tion of traffic }\end{array}$ & $1 / 3$ & 1 & $1 / 4$ & $1 / 7$ & 3 & $1 / 2$ & $1 / 3$ & 0.48 & 0.05 \\
$\begin{array}{l}\text { Congestion of the } \\
\text { daytime parking lots }\end{array}$ & 2 & 4 & 1 & $1 / 2$ & 6 & 8 & 2 & 2.34 & 0.23 \\
$\begin{array}{l}\text { Zoning } \\
\text { Functional value of } \\
\text { the street }\end{array}$ & $1 / 4$ & $1 / 3$ & $1 / 6$ & $1 / 8$ & 1 & $1 / 2$ & $1 / 4$ & 0.30 & 0.03 \\
City category & $1 / 3$ & 2 & $1 / 8$ & $1 / 9$ & 2 & 1 & $1 / 4$ & 0.47 & 0.05 \\
$\begin{array}{l}\text { Demand for parking } \\
\text { lots }\end{array}$ & $1 / 2$ & 3 & $1 / 2$ & $1 / 5$ & 4 & 4 & 1 & 1.13 & 0.11 \\
Total & 7.41 & 20.33 & 4.55 & 2.41 & 28.00 & 26.00 & 10.83 & 10.09 & 1.00 \\
\hline
\end{tabular}

the obtained coherence is acceptable or not, it is necessary to compare the obtained value of the Coherence Index with the value of the Random Index $(R I)$.

The Coherence Ratio is calculated by the formula:

$$
C R=C I / R I
$$

The Random Index for the 7-dimensional matrix is 1.35 . Coherence Ratio is 0.04 . Since the value of Coherence Ratio is $<0.1$, the level of coherence can be considered sufficient. According to the calculations, the most important factor of influence is zoning.

To determine the degree of advantage of one factor over the other, 5-dimensional matrices of pairwise comparisons were constructed for each factor given in Fig. 2.

As a result of the calculations, there were received the following priority coefficients for each of the factors that being analyzed (Table 4).

The Coherence Ratio calculated by formula (6) for each factor does not exceed 0.1 , that is, the degree of coherence can be considered sufficient.

The choosing of zoning coefficient steps to calculate the service cost of using daytime paid vehicle parking lots on a set of factors of influence, shown in Figure 2, is carried out by multiplying the matrices of the priority vectors (formula (7)).

$$
\begin{array}{r}
{\left[\begin{array}{llllll}
0.05 & 0.06 & 0.05 & 0.04 & 0.04 & 0.05 \\
0.06 & 0.07 & 0.08 & 0.06 & 0.48 & 0.08 \\
0.11 & 0.14 & 0.14 & 0.14 & 0.14 & 0.5 \\
0.55 & 0.45 & 0.49 & 0.48 & 0.16 & 0.1 \\
0.23 & 0.28 & 0.24 & 0.28 & 0.18 & 0.2 \\
\times & {\left[\begin{array}{l}
0.14 \\
0.05 \\
0.23 \\
0.39 \\
0.03 \\
0.05 \\
0.11
\end{array}\right]}
\end{array}\right]=\left[\begin{array}{l}
0.045 \\
0.075 \\
0.122 \\
0.44 \\
0.233
\end{array}\right]}
\end{array}
$$

Thus, the final matrix largest value is 0.44 , which corresponds to the coefficient step of the tariff adjustment factor $L_{f 4}=0.4$. Accordingly, the tariff for vehicle parking must be calculated based on the minimum established tariff in a large city, which may make up to 5 UAH per hour. Table 5 presents recommendations on the distribution of the tariff for vehicle parking on daytime parking lots taking into account the step of zoning coefficient. 
Table 4. Top Ten Countries for the Patents in 2017

\begin{tabular}{|l|c|c|}
\hline \multicolumn{1}{|c|}{ Factors } & $\begin{array}{c}\text { Priority } \\
\text { coefficients }\end{array}$ & $P_{i}$ \\
\hline $\begin{array}{l}\text { Congestion of the transport system of } \\
\text { the city }\end{array}$ & $L_{f 4}$ & 0.55 \\
Level of organization of traffic & $L_{f 4}$ & 0.45 \\
Congestion of the daytime parking lots & $L_{f 4}$ & 0.49 \\
Zoning & $L_{f 4}$ & 0.48 \\
Functional value of the street & $L_{f 2}$ & 0.48 \\
City category & $L_{f 3}$ & 0.54 \\
Demand for parking lots & $L_{f 4}$ & 0.51 \\
\hline
\end{tabular}

Table 5. Recommendations on the Distribution of the Tariff for Vehicle Parking on Daytime Parking Lots Given the Step of the Zoning Indicator

\begin{tabular}{|c|c|}
\hline Perspective zone & Tariff \\
\hline Zone I & $7 \mathrm{UAH} \times(1+0.4)=9.8$ UAH per hour \\
Zone II & $5 \mathrm{UAH} \times(1+0.4)=7$ UAH per hour \\
Zone III & 5 UAH per hour \\
\hline
\end{tabular}

As can be seen from Table 5, the step of the zoning indicator makes it possible to differentiate the tariff for vehicle parking on daytime parking lots according to each zone depending on the congestion coefficient.

In order to assess the level of congestion of daytime paid vehicle parking lots, they were tested on the basis of experiments. As a result of the conducted experiments, the average congestion of a daytime paid vehicle parking lot is calculated as the ratio of the actual number of vehicles to the total number of parking places. The results of experimental researches have allowed allocating 3 zones in the studied large city.

During the cluster analysis, 3 clusters were formed. The results of clustering of daytime paid vehicle parking lots showed which objects belong to one or another cluster. The distance from each object to the center of the cluster is determined to confirm assignment of each of them to a specific cluster (zone). This confirms the results of the experiments carried out.

Thus, Zone I includes 27 daytime paid vehicle parking lots with the highest congestion, Zone II has 17 parking lots with average congestion, Zone III includes 6 lots with the lowest congestion rate.

To calculate the zoning indicators and their inclusion in the calculation of the cost for services of using daytime paid vehicle parking lots, the method of hierarchy analysis was used. It allowed substantiating the solution of the multicriterial problem in a complex hierarchical structure, as well as eliminating the subjectivity of experts' evaluations when choosing the factors that have the greatest influence on the choice of the step of the zoning coefficient. For this purpose, a hierarchical model of solving the problem of selecting a step of the zoning coefficient for calculating the cost for services of using daytime paid vehicle parking lots has been constructed.

In assessing the priority of influence factors on the zoning coefficient, the scale of relative importance of T. Saati was used, which confirmed that zoning is the main influencing factor on the step of adjusting the tariff rate for the paid parking of vehicles. Based on the results of calculations, it was determined that the advantage of the zoning coefficient $L_{f 4}=0.4$ is the highest. This coefficient should be used to adjust the tariff to calculate the cost for services of vehicle parking on daytime parking lots.

The development is universal and intended for use at utility enterprises of large cities, which provide vehicle parking services, in particular, when preparing and submitting settlement materials and documents for the formation of tariffs for services of using daytime paid vehicle parking lots.

\section{REFERENCES}

1. Borovikov, V. P. (1998). Popular introduction to the program STATISTICA. Moscow: ComputerPress. URL: http://www. analitika.kz/images/aa1234.pdf (Last accessed: 23.09.2018).

2. Bureeva, N. N. (2007). Multidimensional statistical analysis using the "STATISTICA" software. Educational and methodical material on the advanced training program "Application of software in scientific research and teaching mathematics and mechanics”. Nizhniy Novgorod. URL: http://www.unn.ru/pages/issues/aids/2007/57.pdf (Last accessed: 19.09.2018). 
3. Illyashenko, N. S. (2011). Organizational and economic bases of innovative marketing of industrial enterprises. Sumy: "Publisher SumDU".

4. Saati, T. (1993). Making decisions. Method of analysis of hierarchies. Moscow: Radio and communication.

5. The Law of Ukraine “On Road Traffic” №3353-XII (1993). URL: http://zakon.rada.gov.ua/laws/show /3353-12 (Last accessed: 26.08.2018).

6. The Law of Ukraine “On Improvement of Human Settlements” № 2807-IV (2005). URL: http://zakon.rada.gov.ua/laws/ show/2807-15 (Last accessed: 27.08.2018).

7. The Law of Ukraine "On Amendments to Certain Legislative Acts of Ukraine Regarding the Reform of the Vehicle Parking Field” №2262-VIII (2017). URL: http://zakon.rada.gov.ua/laws/show/2262-19 (Last accessed: 27.08.2018).

8. The resolution of the Cabinet of Ministers of Ukraine "On Approval of Vehicle Parking Rules" № 1342 (2009). URL: http://zakon.rada.gov.ua/laws/show/ 1342-2009-\%D0\%BF (Last accessed: 26.08.2018).

9. The resolution of the Cabinet of Ministers of Ukraine "On approval of the procedure for the formation of tariffs for services for the use of places for paying parking vehicles” № 258 (2010). URL: http://zakon.rada.gov.ua/laws/show/2582010-\%D0\%BF/ (Last accessed: 06.09.2018).

10. The State Building Regulations. Planning and building urban and rural settlements: DBN 360-92**(2011). Kyiv: LLC "LIGA: LAW".

Стаття надійшла до редакції / Received 07.06.19

Статтю прорецензовано / Revised 20.09.19

Статтю підписано до друку / Accepted 07.11.19

Н.М. Внукова ${ }^{1}$, Т.О. Тохтамиш ${ }^{2}$ О.А. Ягольницькийㄹ, К.Б. Гранько ${ }^{2}$

${ }^{1}$ Харківський національний економічний університет імені Семена Кузнеця, просп. Науки, 9-а, Харків, 61166, Україна,

+380 57702 0304, post@hneu.edu.ua

${ }^{2}$ Харківський національний університет будівництва і архітектури,

вул. Сумська, 40, Харків, 61002, Україна,

+380 57700 1056, office@kstuca.kharkov.ua

\section{ІННОВАЦІЙНИЙ ПІДХІД ДО РОЗРАХУНКУ ВАРТОСТІ ПОСЛУГ З ПАРКУВАННЯ ТРАНСПОРТНИХ ЗАСОБІВ}

Вступ. Аналіз стану системи паркування транспортних засобів в Україні свідчить, що організаційні, нормативно-правові та фінансові умови ії функціонування не відповідають потребам учасників дорожнього руху, вимогам користувачів та європейським практикам.

Проблематика. Через перевантаження вулично-дорожньої мережі великих міст України транспортними засобами виникає необхідність обгрунтування та визначення показників зональності для встановлення відповідної вартості послуг за користування майданчиками для платного паркування.

Мета. Розробка показників зональності при розрахунку вартості послуг з користування майданчиками для платного паркування транспортних засобів.

Матеріали та методи. Використано загальнонаукові та спеціальні методи економічної теорії та наукового пізнання: системного, порівняльного аналізу тощо.

Результати. Визначення рівня завантаження денних майданчиків для платного паркування транспортних засобів дозволило виділити три зони. Більша частина майданчиків потрапила до зони I та зони II через рівень їхнього завантаження понад 60 \%. Розроблено показники зональності для розрахунку вартості послуг з користування майданчиками для платного паркування транспортних засобів. При оцінці пріоритету впливу факторів на показник зональності використано шкалу відносної важливості Т. Сааті. Визначено, що зональність $€$ головним фактором впливу на крок коефіцієнту коригування тарифу для платного паркування транспортних засобів. Результати розрахунків показали, що крок коригування тарифу має складати 0,4.

Висновки. Розробку можна використовувати в роботі підприємств комунального господарства, що забезпечують надання послуг з паркування транспортних засобів, зокрема, при підготовці та поданні розрахункових матеріалів та документів для формування тарифів на послуги з користування денними майданчиками для платного паркування транспортних засобів.

Ключові слова: показник зональності, майданчики для паркування, завантаження, транспортні засоби, тариф. 